2010

\title{
Conservation with Justice: A Rights-Based Approach
}

Dinah L. Shelton

George Washington University Law School, dshelton@law.gwu.edu

Thomas Greiber

Melinda Janki

Marcos Orellana

Annalisa Savaresi

Follow this and additional works at: https://scholarship.law.gwu.edu/faculty_publications

Part of the Law Commons

\section{Recommended Citation}

Thomas Greiber, Melinda Janki, Marcos Orellana, Annalisa Savaresi \& Dinah Shelton, Conservation with Justice: A Rights-Based Approach (Int'I Union for Conservation of Nature, Envtal. Law \& Policy Paper No. 71, 2010).

This Article is brought to you for free and open access by the Faculty Scholarship at Scholarly Commons. It has been accepted for inclusion in GW Law Faculty Publications \& Other Works by an authorized administrator of Scholarly Commons. For more information, please contact spagel@law.gwu.edu. 


\section{Conservation with Justice}

A Rights-based Approach

Thomas Greiber, Melinda Janki, Marcos Orellana, Annalisa Savaresi, Dinah Shelton 


\section{A Rights-based Approach to Conservation}

For more than half a century the international community has acknowledged that human rights represent the inherent attributes of the human person and are the cornerstone of a life with dignity. They represent the maximum claims on society and must be respected in all activities in order to ensure justice. At the same time, it has been recognized for more than three decades that human rights and environmental protection, including biodiversity and natural resource conservation, are interrelated fundamental goals of the global community. ${ }^{1}$ The linkages between the two subjects are multidimensional and reciprocal. Several basic principles are generally accepted:?

- Failure to conserve natural resources and biodiversity can undermine human rights - e.g., by destroying resources and ecosystem services on which many people, especially indigenous and local communities, depend.

- However, nature conservation can also support the respect for and fulfilment of human rights e.g., by securing the sustainable availability of critical natural resources and ecosystem services. ${ }^{3}$

- Unfortunately, certain approaches to conservation have the potential to clash with human rights e.g., the designation of protected areas might exclude people who depend on the natural resources found in this area, and climate change mitigation projects might lead to the displacement of people.

- In addition, failure to respect, ensure, and fulfil internationally and domestically guaranteed human rights can be a trigger for environmental destruction - e.g., by ignoring the needs of individuals and groups who can contribute to conservation with justice if they are consulted and are able to participate in decision making about activities, programmes, and policies that may affect them or their surroundings.

Based on this understanding, activities, programmes, and policies can either undermine or support conservation and/or justice. Applying a rights-based approach (RBA) to conservation is expected to be a means to ensure conservation with justice. It is motivated by two main rationales: first, awareness that environmental quality is a prerequisite to ensuring the enjoyment of a host of internationally and domestically guaranteed legal rights and, second, a similar awareness that respect for such rights can lead to better conservation.

See, e.g., the Stockholm Declaration on the Human Environment, Principle 1, and the background papers and final results of the UN High Commission on Human Rights 2002 (Meeting of the Experts on Human Rights and the Environment), available at www.unhchr.ch/environment.

A similar framework of conservation - human rights relationships is described in Campese. J., Sunderland. T., Greiber, T. and Oviedo, G. (eds.) Rights-based approaches: Exploring issues and opportunities for conservation (Bogor, Indonesia: CIFOR and IUCN, 2009).

3 Ecosystem services and the natural resources secured through conservation are critical to the enjoyment of many human rights, among them the rights to life, health, personal security. and an adequate standard of living. 


\section{Box 1: Definitions}

Conservation with justice means that all State and non-State actors planning or engaged in policies, projects, programmes, and activities with potential impact on nature conservation shall secure to all potentially affected persons the substantive and procedural rights that are guaranteed by national and international law.

Conservation, according to IUCN, means management of human use of the biosphere so that it may yield the greatest sustainable benefit to current generations while maintaining its potential to meet the needs and aspirations of future generations. Thus conservation is positive, embracing preservation, maintenance, sustainable utilization, restoration, and enhancement of the natural environment. ${ }^{4}$

An RBA to conservation with justice, properly implemented, should facilitate the achievement of an ecologically sustainable environment, inter- and intragenerational equity, and respect for the intrinsic value of nature. In sum, the RBA to conservation with justice puts an emphasis on conservation but highlights the livelihoods and rights aspects of projects, programmes, and activities.

\section{Advantages and Challenges of a Rights-based Approach}

Implementing an RBA to conservation requires all those involved in conservation activities, programmes, and policies to respect the rights of affected persons if and as they proceed. Those aiming to develop and apply an RBA to conservation are likely to have advantages and also to face several challenges.

One advantage is that an RBA can illuminate the underlying causes of positive or negative impacts of an activity on people's rights, in particular human rights, and conservation, as well as the impact of the enjoyment or lack of enjoyment of people's rights on conservation efforts, thus allowing better choices in designing and carrying out the proposed project or activity.

A second advantage is that the RBA may improve conservation outcomes by facilitating positive synergies and generally improving the governance of natural resources. It can demonstrate the positive contribution that conserving a safe and healthy environment makes to people's rights and, conversely, it can increase awareness of the negative impact on people's rights of failing to protect critical natural resources and biodiversity. In turn, from the perspective of affected persons, the RBA is likely to increase the legitimacy of proposed activities, programmes, and policies by integrating social concerns with conservation goals, drawing on a widely agreed upon set of norms specifying the rights and responsibilities of all actors. Should the activities prove detrimental to the environment or 
people's rights, the RBA can be an effective instrument to ensure the accountability of governments, the private sector, and conservation or human rights organizations.

There are also challenges, however, to developing and implementing an RBA related to conservation. While all States have human rights obligations as members of the United Nations and are bound to comply with both human rights and conservation duties pursuant to treaties they have ratified and their own national laws, not all governments are fully engaged in long-term conservation efforts or the realization of human rights. The commitment of non-State actors to conservation and human rights duties may be even more questionable: the degree to which the private sector is bound by international obligations remains a subject of much discussion - business entities, e.g., may challenge efforts to insist on their compliance with international law. Whatever the outcome of this debate, there is no doubt that all actors are duty-bound to conform to the national laws, including guaranteed rights and conservation laws, of the State where their activities take place. And the State is required to ensure that such actors respect the rights of those within the State.

A second challenge arises from the limitations inherent in the RBA itself. It is predominately about human beings. Global human rights texts contain few references to the environment, and efforts to use human rights-complaint procedures to protect nature or other species have had only limited success. ${ }^{5}$ Yet with close to 115 national constitutions containing rights to a safe, healthy, or ecologically balanced environment, broader guarantees of conservation as itself a right are emerging.

A further challenge may arise from competition between rights, either across groups or within a single group. The right to property, e.g., may be asserted to limit the designation of a protected area, or the exercise of certain cultural rights may appear to infringe on gender equality. This problem is not new or unique, however. Courts throughout the world have had to balance and reconcile constitutional rights pressed by different claimants. The approach most often taken is to arrive at a decision that can maximize the enjoyment of all claimants' various rights rather than one that disproportionately favours one right or group over another.

Finally, the RBA requires substantial resources of time, expertise, information, and funding to build capacity. These deficits may be mitigated or overcome by seeking out partnerships among all the relevant stakeholders.

\section{Understanding Rights}

\section{Sources of Rights}

The RBA is facilitated because all legal systems establish a hierarchy among types of laws, claims, and rights. Constitutional (and sometimes treaty-based) human rights guarantees normally have higher value than other laws or regulations and take precedence over them. Other written laws and regulations derived from the democratic, legislative process in turn generally are given higher value than the customs or unwritten laws of any part of society, and these have greater weight than moral claims.

The Inter-American Commission on Human Rights, e.g., declared a petition inadmissible in which the petitioner asserted that the government had violated the right to property of all Panamanians by authorizing construction of a public roadway through a protected nature reserve. See Case, 11.533 (Panama). Report No. 88/03, Annual Report 2004. 
This, of course, does not mean that laws and the rights they delineate necessarily conflict with moral claims, because human rights guarantees; conservation laws, and many other norms have emerged and derive their power in part from moral or ethical values. The moral and legal weight attached to them is an important factor in promoting their respect not only by governmental actors but by all members of society. However, moral or ethical claims that have not been transformed into legal rights usually are not the source of legal obligation and thus lack a basis for judicial or other formal means of enforcement.

Rights are recognized or formulated by many different types of legal texts. International human rights treaties contain internationally guaranteed minimum standards that are understood to be universal, interdependent, and indivisible ${ }^{5}$ and are guaranteed to all persons without discrimination.

The same and additional rights may also be guaranteed by national or State constitutions. As noted, close to 115 constitutions throughout the world guarantee a right to a clean and healthy environment, impose a duty on the State to prevent environmental harm, or mention the protection of the environment or natural resources. ${ }^{7}$ Over half of the constitutions, including nearly all adopted since 1992, explicitly recognize the right to a clean and healthy environment. The constitutional rights granted in these cases are increasingly being enforced by courts. ${ }^{8}$ In India, e.g., a series of judgments between 1996 and 2000 responded to health concerns caused by industrial pollution in Delhi. ${ }^{9}$ In some instances, the "courts issued orders to cease operations. ${ }^{10}$ The Indian Supreme Court has based the closure orders on the principle that health is of primary importance and that residents are suffering health problems due to pollution. South African courts also have deemed the right to a healthy environment to be justiciable. In Argentina, this is deemed a subjective right entitling any person to initiate an action for environmental protection. ${ }^{11}$ Colombia also recognizes the enforceability of the right to a healthy environment. ${ }^{2}$ In Costa Rica, a court stated

6 Vienna Declaration on Human Rights, 1993.

7 Examples include: Angola ("All citizens shall have the right to live in a healthy and unpolluted environment." Article 24-1); Argentina ("All residents enjoy the right to a healthy, balanced environment which is fit for human development." Article 41); Azerbaijan ("Everyone has the right to live in a healthy environment."); Brazil ("Everyone has the right to an ecologically balanced environment, which is a public good for the people's use and is essential for a healthy life." Article 225).

8 For a discussion of African cases, see Carl Bruch et al., "Constitutional Environmental Law: Giving Force to Fundamental Principles in Africa," 26 Columbia Journal of Environmental Law, vol. 26, no. 1 (2001), p. 131.

9 As early as 1991, the Supreme Court interpreted the right to life guaranteed by Article 21 of the Constitution to include the right to a wholesome environment. See Charan Lal Sahu v. Union of India, AIR 1990 SC 1480 (1991). In a subsequent case, the Court observed that the "right to life guaranteed by Art. 21 includes the right of enjoyment of pollution-free water and air for full enjoyment of life". Subhash Kumar v. State of Bihar, AIR 1991 SC 420, 1991 (1) SCC 598.

10 See, e.g., M.C. Mehta v. Union of India \& Others, JT 1996, reprinted in 1 The Environmental Activists' Handbook, p. 631.

11 Kattan, Alberto and Others v. National Government, Juzgado Nacional de la Instancia en lo Contencioso Administrativo Federal. No. 2, ruling of 10 May 1983, La Ley, 1983-D, 576; Irazu Margarita v. Copetro S.A. , Camara Civil y Comercial de la Plata, ruling of 10 May 1993, available at www.eldial.com ("The right to live in a healthy and balanced environment is a fundamental attribute of people. Any aggression to the environment ends up becoming a threat to life itself and to the psychological and physical integrity of the person.").

12 Funde publico v. Mayor of Bugalagrande and Others, Juzgado Primero superior, Interlocutorio \#l 032, Tulua, 19 December 1991 ("It should be recognized that a healthy environment is a sina qua non condition for life itsself and that no right could be exercised in a deeply altered environment."). 
that the right to health and to a clean environment is necessary to ensure that the right to life is fully enjoyed. ${ }^{13}$

Statutory rights add further protections, often detailing the modalities of the exercise of certain rights, such as the right to participate in environmental impact assessment (EIA) procedures. Customary rights become legal rights only if they are recognized by statutory laws.

\section{$2 \quad$ Rights and Obligations}

Whatever their legal formulation, it is important to understand that rights are reciprocal in the sense that the rights of one person end where the rights of another person begin. In other words, all rights are coupled by duties towards other persons and society as a whole. In the language of Article 29 (1) of the Universal Declaration of Human Rights (New York, 10 December 1948): "Everyone has duties to the community in which alone the free and full development of his personality is possible." Thus the exercise of rights and freedoms may be limited to secure the rights and freedoms of others and the general welfare of others, provided the limitations are determined by law and are necessary, proportionate, and non-discriminatory.

A corollary to the RBA to conservation is that duty-bearers (States, multilateral agencies, business entities, organizations, and individuals) have obligations to respect, protect, guarantee, and promote people's rights and to respect international and national norms concerning conservation. The two goals should be mutually reinforcing and lead States to adopt and implement a minimum set of public policies, laws, and regulations.

Each State has positive and negative obligations with respect to securing the rights of those within its territory and subject to its jurisdiction. ${ }^{14} \mathrm{~A}$ few international human rights agreements, such as the Covenant on Economic, Social and Cultural Rights, also contain references to transnational obligations. According to Article 2 of the Covenant, each State party undertakes to take steps not only individually but "through international assistance and cooperation, especially economic and technical," to achieve the full realization of the rights contained therein. ${ }^{15}$

13 Presidente de la Sociedad Marlene S.A. v. Municipalidad de Tibas, Sala Constitucional de la Corte Supreme de Justicia. Decision No. 6918/94 of 25 November 1994.

14 See General Comments of the Committee on Economic, Social and Cultural Rights; Inter-American Court of Human Rights, Velazzquez Rodriguez Case, judgment of 29 July 1988. Series C, No. 4; and Social and Economic Rights Action Center and Center for Economic and Social Rights v Nigeria, African Commission on Human and Peoples' Rights, Communication No. 155/96, October 2001.

15 While Article 2 grants States necessary discretion and flexibility corresponding to their capabilities, it also imposes some immediate obligations. State actions must be non-discriminatory, States must commit the maximum possible resources to fulfilment of the guaranteed rights, and priority should be given "to ensur[ing] the satisfaction of, at the very least, minimum essential levels of each of the rights". ICESCR GC No 3, The Naturo of States Parties' Obligations (art. 2, para. 1, of the Covenant), para. 10. 


\section{Box 2: Positive and Negative Obligations to Secure Rights}

Respect for rights means abstention from violating or directly or indirectly interfering with an individual's pursuit or enjoyment of guaranteed rights.

Protection of rights means ensuring the observance of rights through control, monitoring, investigation, and enforcement.

Constitutional or statutory guarantees may repeat, reinforce, or add to international minimum standards. In addition, national law may guarantee rights not only against State agents, organs, and actions but against private actors. This in turn means that private actors have their own obligations to respect and protect the rights of others in alt their activities, including by sustainable use and conservation of resources. Those involved in activities or projects thus should ensure through prior evaluation of the scope of the activity or project that all potentially affected persons are identified, informed, and consulted. Such planning can ensure that each actor respects and protects guaranteed rights during the life of the project or activity. However, it is important to keep in mind that even in the absence of State regulation, non-State actors should apply an RBA to conservation by conforming their conduct to international norms of human rights and conservation. This is indispensable if they not only admit a social responsibility - which is generally the case - but also take this responsibility seriously and live up to it.

\section{Substantive and Procedural Rights}

Rights recognized in international and national law today cover numerous dimensions of human wellbeing and dignity but may be divided generally into substantive and procedural rights.

\section{Substantive Rights}

At the concluding session of the 1972 Stockholm Conference, the participants adopted the Declaration of the United Nations Conference on the Human Environment (Stockholm, 16 June 1972), which established a foundation for linking human rights and environmental protection in law. Principle 1 declared that "Man has the fundamental right to freedom, equality and adequate conditions of life, in an environment of a quality that permits a life of dignity and well-being".

The necessity of environmental protection to the enjoyment of human rights has also been recognized by international human rights bodies, such as the Inter-American Commission on Human Rights:

The American Convention on Human Rights (San Jose, 22 November, 1969) is premised on the principle that rights inhere in the individual simply by virtue of being human. Respect for the inherent dignity of the person is the principle which underlies the fundamental protections of the right to life and to preservation of physical well-being. Conditions of severe environmental 
pollution, which may cause serious physical illness, impairment and suffering on the part of the local populace, are inconsistent with the right to be respected as a human being. ${ }^{16}$

Furthermore, while many human rights treaties were written before environmental matters or nature conservation were fully considered on the international agenda, there are several relevant textual references.

For example, the International Covenant on Economic, Social and Cultural Rights (New York, 16 December 1966) speaks primarily to the working environment, guaranteeing the right to safe and healthy working conditions (Article $7 \mathrm{~b}$ ) and the right of children and young persons to be free from work harmful to their health (Article 10 para. 3). The right to health (Article 12) expressly calls on States parties to take steps for "the improvement of all aspects of environmental and industrial hygiene" and "the prevention, treatment and control of epidemic, endemic, occupational, and other diseases".

The Convention on the Rights of the Child (New York, 20 November 1989) similarly refers to some dimensions of environmental protection in respect to the child's right to health. Article 24 provides that States parties shall take appropriate measures to combat disease and malnutrition "through the provision of adequate nutritious foods and clean drinking water, taking into consideration the dangers and risks of environmental pollution" (Article 24 (2) (c)). States parties also are to provide information and education on hygiene and environmental sanitation to all segments of society (Article $24(2)(e))$.

ILO Convention No. 169 concerning Indigenous and Tribal Peoples in Independent Countries (Geneva, 27 June 1989) contains numerous references to the lands, resources, and environment of indigenous peoples (e.g., Articles 2, 6, 7, and 15). The convention requires States parties to take special measures to safeguard the environment of indigenous peoples (Article 4). In particular, governments must provide for environmental impact studies of planned development activities and take measures, in cooperation with the peoples concerned, to protect and preserve the environment of the territories they inhabit.

The most recent UN human rights text, the United Nations Declaration on the Rights of Indigenous Peoples (New York, 13 September 2007) adopted by the General Assembly with only four dissenting votes, contains several provisions relating human rights and environmental conditions. In addition to protection of indigenous lands (Articles 10, $25-27$ ) and resources (Articles 23, 26), the declaration contains procedural rights of participation (Article 18) and prior informed consent (PIC) (Article 19) as well as a specific article on conservation. Article 29 states that:

1. Indigenous peoples have the right to the conservation and protection of the environment and the productive capacity of their lands or territories and resources. States shall establish and implement assistance programmes for indigenous peoples for such conservation and protection, without discrimination. 
2. States shall take effective measures to ensure that no storage or disposal of hazardous materials shall take place in the lands or territories of indigenous peoples without their free, prior and informed consent.

3. States shall also take effective measures to ensure, as needed, that programmes for monitoring, maintaining and restoring the health of indigenous peoples, as developed and implemented by the peoples affected by such materials, are duly implemented.

On the regional level, the African Charter on Human and Peoples' Rights (Banjul, 26 June 1981) in Article 24 sets forth that "All peoples shall have the right to a general satisfactory environment favorable to their development".

The Additional Protocol to the American Convention on Human Rights in the area of Economic, Social and Cultural Rights (San Salvador, 17 November 1988) similarly contains a right to environmental quality, although the guarantee is not subject to the Inter-American system's individual complaint procedure. ${ }^{17}$ Article 11, entitled "Right to a Healthy Environment", proclaims:

1. Everyone shall have the right to live in a healthy environment and to have access to basic public services.

2. The States parties shall promote the protection, preservation and improvement of the environment.

The 2004 Revised Arab Charter on Human Rights (Tunis, 22 May 2004) also contains the right to a safe and healthy environment. Its Article 38 specifies:

Every person has the right to an adequate standard of living for himself and his family that ensures their well-being and a decent life, including food, clothing, housing, services and the right to a healthy environment. The States parties shall take the necessary measures commensurate with their resources to guarantee these rights.

This shows that environmental protection is undoubtedly recognized as a precondition to the enjoyment of some internationally guaranteed human rights, especially the rights to life, health, private and home life, and culture. It directly or indirectly has an impact on other rights as well, such as the right to work and to education. Environmental protection is thus an essential instrument in the effort to secure the effective enjoyment of human rights. Such preconditions to the enjoyment of fundamental rights may be elevated to the status of rights themselves, as happened with the right to equality and nondiscrimination and is increasingly the case with environmental quality itself. 


\section{Box 3: List of Relevant Substantive Rights}

- Nondiscrimination and equal protection of the law

- Right to life

- Prohibition of force and child labour

- Freedom of movement and residence

- Right to privacy and home life

- Right to property

- Freedom of religion

- Right to an adequate standard of living (food, medicine, clothing, housing, water)

- Cultural rights

- Minority rights

- Right to safe and healthy working conditions

- Freedom of assembly and expression/opinion

- Right to health

- Right to privacy

- Right to self-determination of peoples (controversial)

- Right to a certain quality of environment (controversial; certain aspects of this right have a global consensus, such as safe drinking water, and nutritious food)

\section{Procedural Rights}

Procedural rights play an equally important role in the development of an RBA to conservation, since they are essential for supporting as well as ensuring the actual implementation of and compliance with substantive rights.

This approach is illustrated by Principle 10 of the 1992 Rio Declaration on Environment and Development (Rio de Janeiro, 14 June 1992), which declares that access to information, public participation in decision making, and access to effective judicial and administrative proceedings, including redress and remedy, shall be guaranteed because "environmental issues are best handled with the participation of all concerned citizens, at the relevant level". The same procedural rights are commonly guaranteed in environmental treaties. ${ }^{19} \mathrm{~A}$ few examples of this approach are indicative.

18 See, also Convention on Access to Information, Public Participation and Access to Justice in Environmental Matters (Aarhus, 25 June 1998); Protocol to the 1979 Convention on Long-Range Transboundary Air Pollution Concerning the Control of Emissions of Volatile Organic Compounds or Their Transboundary Fluxes (Geneva, 18 November 1991), Article 2 (3) (a) (4); Convention on the Protection and Utilization of Transboundary Rivers and Lakes (Helsinki, 17 March 1992). Article 16; Convention on Civil Responsibility for Damage Resulting from Activities Dangerous to the Environment (Lugano, 21 June 1993). Articles 13-16; United Nations Framework Convention on Climate Change (Rio de Janeiro, 9 May 1992). Article 6; Protocol on Water and Health to the 1992 Convention on the Protection and Use of Transboundary Watercourses and International Lakes (London, 17 June 1999); Convention on the Transboundary Effects of Industrial Accidents (Helsinki, 17 March 1992); and Convention on Environmental Impact Assessment in a Transboundary Context (Espoo, 25 February 1991), Article 1 (viii). 
The United Nations Convention to Combat Desertification in Countries Experiencing Serious Drought and/or Desertification, Particularly in Africa (Paris, 17 June 1994), for instance, places human beings at the centre of concern to combat desertification (Preamble) and requires States parties to ensure that all decisions to combat desertification or to mitigate the effects of drought are taken with the participation of populations and local communities (Article 3). The convention emphasizes throughout information and the participation of local communities.

The Rotterdam Convention on the Prior Informed Consent Procedure for Certain Hazardous Chemicals and Pesticides in International Trade (Rotterdam, 10 September 1998) in Article 15 (2) requires each State party to ensure, to the extent practicable, that the public has appropriate access to information on chemical handling and accident management and on alternatives that are safer for human health or the environment than the chemicals listed in Annex III to the convention.

The Cartagena Protocol on Biosafety (Montreal, 29 January 2000) to the Convention on Biological Diversity (CBD) requires the parties to facilitate awareness, education, and participation concerning the safe transfer, handling, and use of living modified organisms in relation to the conservation and sustainable use of biological diversity, taking into account risks to human health. Access to information on imported living modified organisms should be ensured and the public consulted in the decision-making process regarding such organisms, with the results of such decisions made available to the public. Further, each party shall endeavour to inform its public about the means of public access to the Biosafety Clearing-House created by the convention.

These examples illustrate that procedural rights have special relevance for the development and implementation of an RBA to conservation. An emphasis on rights of information, participation, and access to justice encourages an integration of democratic values and promotion of the rule of law in broad-based structures of governance. Thus, ensuring these rights is not only a way to produce decisions favourable to environmental protection, it can reinforce respect for human rights, the rule of law, and good governance more generally. Experience suggests that "governments that show a disregard for their citizens' basic rights often protect the environment poorly as well"19 and that citizen efforts to counter environmental harm tend to promote human rights as well as enhance compliance with environmental norms.

More generally, fairness in procedure is important to ensure the legitimacy and thus acceptance within society of all proposed projects and activities. In law-making or governance, the process by which rules or activities emerge and proposals are adopted is highly important to legitimacy, and legitimacy in turn affects compliance. To a large extent, legitimacy is a matter of participation: the governed must have and perceive that they have a voice in governance through representation, deliberation, or some other form of action.

19 Hari M. Osofsky, "Learning from Environmental Justice: A New Model for International Environmental flights," Stanford Environmental Law Journal, vol. 24 (2005), pp. 71, 88. 


\section{Box 4: List of Procedural Rights}

- Access to information

- Participation in decision making

- Access to justice/judicial review

- Due process/fair hearing

- Substantive redress

- Noninterference with international petition (where applicable)

\section{$4 \quad$ Rights in Practice}

Some of the rights that can be linked to nature conservation and are most often invoked are discussed in this section.

\section{The Right to Life}

The right to life, enshrined in Article 3 of the Universal Declaration of Human Rights and Article 6 of the International Covenant on Civil and Political Rights, is regarded as the most important right, because without respect for it all other rights would be devoid of meaning. It is a right for which no derogation is permitted, even in times of emergency that threaten the life of the nation. The right to life involves not only a prohibition on the intentional but also the negligent taking of life, thus requiring compensation in cases in which death results - e.g., from the release of toxic products into the environment. It also encompasses an obligation to take positive measures - ensuring the safety of local populations when hazardous products or activities are present, for example, or reducing infant mortality and protecting against malnutrition and epidemics. ${ }^{20}$

The UN Human Rights Committee has received several complaints concerning environmental damage as a violation of one or more guaranteed civil and political rights. In one case, a group of Canadian citizens alleged that the storage of radioactive waste near their homes threatened the right to life of present and future generations. The committee found that the case raised "serious issues with regard to the obligation of States parties to protect human life", but declared the case inadmissible due to failure to exhaust local remedies. ${ }^{21}$

Similarly, the Inter-American Commission on Human Rights has determined that enjoyment of the right to life depends on environmental conditions:

The realization of the right to life, and to physical security and integrity is necessarily related to and in some ways dependent upon one's physical environment. Accordingly, where environmental contamination and degradation pose a persistent threat to human life and health, the foregoing rights are implicated."

20 See the General Comment on Article 6 of the Civil and Political Covenant, issued by the United Nations Human Rights Committee, in Compilation of General Comments and General Recommendations Adopted by Human Rights Treaty Bodies, UN Doc. HRI/GEN/1/Rev.3 (1997), pp. 6-7.

21 Communication No. 67/1980, EHP v. Canada, 2 Selected Decisions of the Human Rights Committee (1990), p. 20. Inter-American Commission on Human Rights, op. cit. note 16, p. 88. 
Positive obligations emerge from an individual's right to have his or her life respected and protected by law. ${ }^{23}$ As stated by the Inter-American Commission:

States parties are required to take certain positive measures to safeguard life and physical integrity. Severe environmental pollution may pose a threat to human life and health, and in the appropriate case give rise to an obligation on the part of a State to take reasonable measures to prevent such risk, or the necessary measures to respond when persons have suffered injury. ${ }^{2+}$

In particular, the necessary measures must be taken to remedy existing pollution and to prevent future contamination that would threaten peoples' lives and health, including through addressing risks associated with hazardous development activities, such as mining. ${ }^{25}$

\section{The Right to Health}

Every human being is entitled to the enjoyment of the highest attainable standard of health. The Committee on Economic, Social and Cultural Rights has specified that the right to health "embraces a wide range of socio-economic factors that promote conditions in which people can lead a healthy life and extends to the underlying determinants of health, such as food and nutrition, housing, access to safe and potable water and adequate sanitation, safe and healthy working conditions and a healthy environment". 25

In the case of Yanomami v. Brazil, ${ }^{27}$ the petition alleged that the government violated the American Declaration of the Rights and Duties of Man (Bogota, April 1948) by its own actions in constructing a highway through Yanomami territory and by authorizing private exploitation of the territory's resources. ${ }^{23}$ These actions had generated the influx of non-indigenous persons who brought contagious diseases that remained untreated due to lack of medical care. ${ }^{29}$ The Inter-American Commission on Human Rights found that the government had violated the Yanomamis' rights to life, liberty, and personal security guaranteed by Article I of the Declaration, as well as the right of residence and movement (Article VIII) and the right to the preservation of health and well-being (Article Xl). ${ }^{30}$ The violations were due specifically to the government's failure to implement measures of "prior and adequate protection for the safety and health of the Yanomami Indians"."31

But the realization of the right to health is not limited to measures that prevent human exposure to toxic and hazardous substances or to diseases. Specific nature conservation measures can be required to avoid infringements of the right to health. For example, the United Nations Convention to Combat Desertification clarifies that "desertification and drought affect sustainable development through their interrelationships with important social problems such as poverty, poor health and

Article 4 (1) of the American Declaration of Human Rights and Duties (1948) reads: "Every person has the right to have his life respected. This right shall be protected by law... No one shall be arbitrarily deprived of his life."

24 Inter-American Commission on Human Rights, op. cit. note 16, p. 88.

25 Ibid., p. 94. See also Oneryildiz v. Turkey, Eur.Ct.H.R. (GC, 30 November 2004).

26 Committee on Economic, Social and Cultural Rights, General Comment No. 14 (2000), para. 4.

27 Yanomami Case, Res. No. 12/85, Case 7615 (Brazil), in Annual Report of the IACHR 1984-1985, OEA Ser.LN/II.66, doc. 10, rev. 1 (1985), p. 24.

28 Ibid., pp. 29-30.

29 Ibid.

30 Ibid., p. 33.

31 Ibid., p. 32. 
nutrition, lack of food security, and those arising from migration, displacement of persons and demographic dynamics" (Preamble). The convention sees the phenomenon of desertification as resulting not only from drought but from land degradation linked to loss of natural vegetation (Article 1 (f)). Furthermore, ambient air quality, which has a direct impact on human health, depends in part on the maintenance of forests or other green spaces. Also, the loss of biodiversity can result in famine, since the productivity of ecosystems and presumably their resilience to emerging diseases or pests is connected with the maintenance of biodiversity.

\section{The Right to an Adequate Standard of Living}

The right to an adequate standard of living encompasses food, housing, and clothing. Food should be adequate in quantity and quality, free from adverse substances, and acceptable within a given culture. ${ }^{32}$ Water should be free from contamination and fit for human consumption. Soil, water, and crops should be assessed to ensure quality is preserved.

The Committee on Economic, Social and Cultural Rights has pursued such questions in monitoring State reports. In 1986 Tunisia reported to the committee, in the context of Article 11 of the International Covenant on Economic, Social and Cultural Rights on the right to an adequate standard of living, on measures taken to prevent degradation of natural resources, particularly erosion, and about measures to prevent contamination of food. ${ }^{33}$ The committee has referred to environmental issues in its General Comment on the Right to Adequate Food and its General Comment on the Right to Adequate Housing. In the first, it interpreted the phrase "free from adverse substances" in Article 11 of the Covenant to mean that the State must adopt food safety and other protective measures to prevent contamination through "bad environmental hygiene". ${ }^{34}$ The comment on housing states that "housing should not be built on polluted sites or in proximity to pollution sources that threaten the right to health of the inhabitants". ${ }^{35}$

\section{The Right to Work}

The right to work is enshrined in Article 23 of the Universal Declaration of Human Rights and many human rights treaties. Guarantees for safe and healthy working conditions are contained and detailed in dozens of ILO conventions and recommendations. The right to work can be affected when toxic and hazardous substances are released into the environment (e.g., pesticide pollution affecting agricultural workers) or when noise levels are dangerously high. But infringements on the right to work may also stem from other activities or events that have a direct impact on ecosystems and their services, such as oil spills that contaminate water ecosystems and decimate the fish stocks or the degradation of natural sites that leads to the loss of tourism jobs.

32 Committee on Economic, Social and Cultural Rights, General Comment No, 12 (1999), E/C.12/1999/5. para. 8.

33 Committee on Economic, Social and Cultural Rights. First Periodic Report of Tunisia, E/1986/3/Add.9.

34 Committee on Economic, Social and Cultural Rights, op. cit. note 32, para. 10.

35 General Comment 4 of Dec. 13, 1991, United Nations, Compilation, HRV/GEN/1/Rev.3, 63, para. 5. 


\section{The Rights to Religion and Culture}

There are over 200 million indigenous and triba! people in the world and many of them live in some of the world's most vulnerable ecosystems: the Arctic and tundra, the tropical rainforests, the boreal forests, riverine and coastal zones, mountains, and semiarid rangelands. These territories used and occupied by indigenous peoples are often seen as important repositories of unexploited riches. According to the views of many indigenous peoples, land should not be torn open and exploited, which they consider a violation of Earth, nor can it be bought, sold, or bartered. There are sacred sites and other religious beliefs implicated. Furthermore, indigenous peoples have, over a long period of time, developed successful systems of land use and resource management. These systems including nomadic pastoralism, shifting cultivation, various forms of agro-forestry, terrace agriculture, hunting, herding, and fishing - were for a long time considered inefficient, unproductive, and primitive. The notion of sustainability is the essence of both indigenous economies and their cultures.

Thus the cultural and religious rights of indigenous peoples are particularly affected by exploitation of their lands and resources and consequent environmental harm. As found by the Special Rapporteur on Human Rights and the Environment:

Indigenous peoples have a special relationship with the land and the environment in which they live. In nearly all indigenous cultures, the land is revered; "Mother Earth" is the core of their culture. The land is the home of the ancestors, the provider of everyday material needs, and the future held in trust for coming generations. ${ }^{36}$

In the Toledo Maya case, the Inter-American Commission acknowledged the importance of economic development for the prosperity of the populations of the western hemisphere but insisted that "development activities must be accompanied by appropriate and effective measures to ensure that they do not proceed at the expense of the fundamental rights of persons who may be particularly and negatively affected, including indigenous communities and the environment upon which they depend for their physical, cultural and spiritual well-being". ${ }^{37}$

The balance between minority or indigenous rights and the protection of marine living resources was also at stake in Apirana Mahuika et al. v. New Zealand: ${ }^{38}$ In this case, the government of New Zealand acknowledged on the one hand its duty to ensure recognition of the right to culture, including the right to engage in fishing activities. On the other hand, it referred to its "duty to all New Zealanders to conserve and manage the resource for future generations... based on the reasonable and objective needs of overall sustainable management". The Human Rights Committee emphasized "that the acceptability of measures that affect or interfere with the culturally significant economic activities of a minority depends on whether the members of the minority in question have had the opportunity to participate in the decision-making process in relation to these measures and whether they will continue to benefit from their traditional economy".

36 Commission on Human Rights, Human Rights and the Environment, Preliminary Report Prepared by Mrs. Fatma Zhora Ksentini, Special Rapporteur, E/CN.4/Sub.2/1991/8, 2 August 1991, para. 25.

37 Maya Indigenous Communities of the Toledo District v. Belize, Report N'40/04, Case 12.053 (Merits), 12 October 2004, para. 150.

38 Communication No. 547/1992, Apirana Mahuika et al. v. New Zealand, U.N. doc CCPR/C/70/D/547/1993, views issued 16 November 2000. 


\section{The Right to Property}

The right to use and enjoy property may be impeded when the State itself, or third parties acting with the acquiescence or tolerance of the State, affect the existence, value, use, or enjoyment of that property without due consideration of and informed consultations with those having rights in the property.

The Inter-American Human Rights Court has given a broad interpretation to the notion of "property", extending it to communally owned lands and even to lands occupied and used by indigenous peoples that are not considered by them to be "owned". A landmark case in this context is Awas Tingni Mayagna (Sumo) Indigenous Community v. Nicaragua, ${ }^{39}$ which originated as an action against government-sponsored logging of timber on indigenous lands of the Awas Tingni community. The Awas Tingis' complaint to the Inter-American Commission alleged that the government violated their rights to property, cultural integrity, religion, equal protection, and participation in government. The Inter-American Human Rights Court held that there were violations and unanimously declared that the State must adopt domestic laws, administrative regulations, and other necessary means to create effective surveying, demarcating, and title mechanisms for the properties of the indigenous communities, in accordance with customary law and indigenous values, uses, and customs. Pending the demarcation of the indigenous lands, the State must abstain from realizing acts or allowing the realization of acts by its agents or third parties that could affect the existence, value, use, or enjoyment of the properties located in the Awas Tingni lands. By a vote of seven to one, the Court also declared that the State must invest US\$50,000 in public works and services of collective benefit to the Awas Tingni as a form of reparations for nonmaterial injury and US $\$ 30,000$ for legal fees and expenses. In this regard, the issuance by States of natural resource concessions to third parties in respect of the ancestral territory of indigenous people may contravene the rights of those indigenous communities. ${ }^{40}$

However, in its 2007 judgment in the case of the Saramaka People v. Suriname, ${ }^{+1}$ the Inter-American Court distinguished subsistence resources and other resources. The Court easily concluded that resources related to agricultural, hunting, and fishing activities are protected as subsistence activities and that no activities respecting them can occur without the prior informed consent of the people. As for activities involving other resources, the Court struck a balance. It noted that clean water is essential to the subsistence activity of fishing and that water quality is likely to be affected by the extraction of resources not traditionally used or essential for the survival of the Saramaka. In fact, all extractive activities are likely to affect the use and enjoyment of other resources necessary to the people. However, the Court noted that the protection of the right to property is not absolute and cannot be read to preclude all concessions for exploration and extraction in the Saramaka territory. ${ }^{+2}$ The American Convention on Human Rights, Article 21, itself provides for the limitation of property rights under certain circumstances. In deciding whether such limitations are permissible, the Court set forth three safeguards it deemed essential:

Awas Tingni Mayagna (Sumo) Indigenous Community v. Nicaragua, Inter-American Court of Human Rights, judgment of 31 August 2001.

$40 \quad$ Ibid., para. 153.

41 Case of the Saramaka People v. Suriname, judgment of 28 November 2007.

42 Ibid., paras. 125-126. 
1 the State must ensure the effective participation of the members of the Saramaka people, in conformity with their customs and traditions, regarding any development, investment, exploration or extraction plan within Saramaka territory;

2 the State must guarantee that the Saramakas will receive a reasonable benefit from any such plan within their territory; and

3 the State must ensure that no concession will be issued within Saramaka territory unless and until independent and technically capable entities, with the State's supervision, perform a prior environmental and social impact assessment. ${ }^{43}$

In support of this decision, the Court cited the views of the UN Human Rights Committee, ${ }^{44}$ ILO Convention No. 169, World Bank policies, ${ }^{45}$ and the 2007 UN Declaration on the Rights of Indigenous Peoples. The Court viewed benefit-sharing as inherent to the right of compensation recognized under Article 21 (2) of the American Convention on Human Rights, ${ }^{46}$ and this extends to compensation for any deprivation of the regular use and enjoyment of property. Finally, the Court held that large-scale development or investment projects that would have a major impact within Saramaka territory can only proceed with the free, prior, and informed consent of the people, according to their customs and traditions.

\section{The Right to Privacy and Home Life}

The right to privacy and home life can be found, for example, in the European Convention on Human Rights (Rome, 4 November 1950). Article 8 (1) provides that "everyone has the right to respect for his privacy, his home and his correspondence".

Most of the environmental decisions in the European Court of Human Rights have concerned this right to privacy and family life. The Court has consistently held that environmental harm attributable to State action or inaction that has significant injurious effect on a person's home or private and family life constitutes a breach of Article 8 (1). ${ }^{47}$ Violations may, for example, occur when national authorities do not respect constitutional or statutory environmental rights. ${ }^{48}$

The harm may, however, be excused under Article $8(2)^{49}$ if it results from an authorized activity of economic benefit to the community in general, as long as there is no disproportionate burden on any particular individual; that is, the measures must have a legitimate aim, be lawfully enacted,

43 ibid., para. 129.

44 See ICCPR, General Comment No. 23, The Rights of Minorities (Article 27), U.N. Doc. CCPR/C/21 Rev 1/Add.5, Aug. 4, 1994; and Apirana Mahuika et al. v. New Zealand, U.N. doc CCPR/C/70/D/47/1993, 15 November 2000.

45 See World Bank, Revised Operational Policy and Bank Procedure on Indigenous Peoples, OP/BP 4.10 (Washington, DC).

46 Article 21 (2) provides that "[n]o one shall be deprived of his property except upon payment of just compensation, for reasons of public utility or social interest, and in the cases and according to the forms established by law".

47 See Lopez-Ostra v. Spain, 303C Eur.Ct. Hum.Rts. (ser. A) (1994).

48 See ECHR, Okyay and Others v. Turkey (App. no. 36220/97, judgment of 12 July 2005).

49 Paragraph 2 provides: "There shall be no interference by a public authority with the exercise of this right except such as is in accordance with the law and is necessary in a democratic society in the interests of national security, public safety or the economic well-being of the country, for the prevention of disorder or crime, for the protection of health and morals, or for the protection of the rights and freedoms of others." 
and be proportional..$^{50}$ In this regard, States enjoy a certain discretion or "margin of appreciation" in determining the legitimacy of the aim pursued.

It is important to note that, as with the right to property, the right to privacy and home life is not violated when reasonable environmental protection measures are taken that limit the use of property. As a consequence, the European Court of Human Rights upheld planning restrictions imposed to preserve natural areas. However, compensation may be required. ${ }^{51}$

\section{The Rights to Information and Participation}

Lack of information may exacerbate adverse effects on the rights already discussed by preventing affected people from taking the necessary measures to mitigate adverse effects on their rights.

In the case of Claude Reyes et al. v. Chile, 52 the applicant nongovernmental organizations (NGOs) and individuals, including Chilean legislative representatives, alleged that the State of Chile violated the right to freedom of expression and free access to State-held information (Article 13 of the American Convention on Human Rights) when the Chilean Committee on Foreign Investment omitted releasing information about a deforestation project the petitioners wanted to evaluate. Also, the domestic courts' refusal to admit the subsequent case against the State allegedly constituted a violation of the right to judicial protection (Article 25). While the State argued that the requested information had to be considered confidential and that the release of the information would constitute arbitrary discrimination against the investors, the Inter-American Human Rights Court disagreed. In its judgment finding violations of the right to information and the right to judicial remedies, the Court cited a wide range of documents, including not only declarations of the Organization of American States on democratic governance and its own jurisprudence but also Principle 10 of the Rio Declaration on Environment and Development, resolutions of the Committee of Ministers and Parliamentary Assembly of the Council of Europe, and the Aarhus Convention on Information, Public Participation and Access to Justice. The Court directed the government to devise the means to ensure access to information and provide the information sought by the applicants.

\section{$5 \quad$ Accountability and Good Governance}

The implementation of rights and obligations, and thus the application of an RBA to conservation, will only be effective if good governance is ensured and the different actors are held accountable.

Accountability is coupled with the existence of monitoring and compliance mechanisms. As shown in the previous section, international supervisory bodies have elaborated indicators for many of the guaranteed rights that can be used to assess whether or not the rights are being enjoyed in practice. These indicators can be found in the General Comments issued by bodies like the UN's Human Rights Committee (for civil and political rights); the Committee on Economic, Social and Cultural Rights; and the Committee on the Elimination of All Forms of Racial Discrimination. One 
of the most important of the General Comments concerns the right to water and contains detailed criteria on implementation and monitoring. ${ }^{53}$

In addition to the work of the treaty bodies, the UNHuman Rights Council appoints Special Rapporteurs or Working Groups to evaluate the enjoyment of and compliance with specific human rights related to environmental conditions, such as the right to food, the right to housing, freedom of religion, and the right to health. Their annual reports to the council provide another source of indicators that can be adopted or adapted to ensure that projects or activities do not affect conservation in ways that violate human rights, thus conforming with an RBA to conservation. ${ }^{54}$ On matters of forced and child labour, and on working conditions generally, the International Labour Organization establishes standards and guidelines..$^{55}$

Another source of detail about rights and obligations linked to conservation is the jurisprudence of international tribunals and review bodies. Most human rights treaties and some environmental agreements allow individuals or groups whose rights have been violated to bring complaints or communications to such bodies, which make factual findings and issue recommendations. If a violation occurs, individuals and groups can submit communications or file complaints with global or regional tribunals or review bodies ${ }^{56}$ against the State allegedly responsible, provided the State is a party to the relevant legal instrument. ${ }^{57}$ There is no international procedure where claims can be brought against non-State actors, but they may be held accountable at the national level if they fail to respect guaranteed rights and conservation laws.

Through the decisions of global and regional bodies, 'it is possible to see how environmental and conservation impacts interrelate with human rights violations and understand the duties that are imposed on different actors and, in some instances, to get compensation or be awarded other relief. In any case, exhaustion of local remedies is a prerequisite to gaining access to international procedures, allowing and encouraging the State to redress harm.

With greater attention now being given, to compliance with human rights guarantees, the accountability of non-State actors has also increasingly been raised as an issue in financial institutions, intergovernmental organizations (IGOs), and litigation. In response, IGOs and NGOs like major business enterprises - have developed codes of conduct that include measures to respect and protect human rights and to conserve natural resources and the environment. Such codes can be useful tools in developing and guiding the implementation of an RBA to conservation, either by

53 At its twenty-ninth session, the Committee on Economic, Social and Cultural Rights adopted General Comment No. 15 on "The Right to Water" (Articles 11 and 12 of the Covenant) (E/C.12/2002/11).

54 United Nations human rights sources mentioned can be obtained through the U.N.'s Office of the High Commissioner for Human Rights at www.ohchr.org.

55 See www.ilo.org.

56 In addition to complaints procedures establisted by human rights treaties, the Aarhus Convention on Information, Public Participation and Access to Justice in Environmental Matters has created a non-compliance mechanism that allows complaints to be brought for violations of the procedural rights it guarantees.

57 Human rights complaints procedures exist in relation to the International Covenant on Civil and Political Rights, the International Convention on the Elimination of All Forms of Racial Discrimination, the International Convention on the Elimination of Discrimination Against Women, and ILO Conventions, as well as in UNESCO. The three regional human rights systems - for Europe, tho Americas, and Africa - also have complaints procedures. 
each actor independently or through partnerships among stakeholders and related organizations. Many codes of conduct have been made public and are available online. ${ }^{58}$

Governance, the exercise of authority, is also an important aspect of the RBA. Natural resource governance can be described as: Who has the power to make decisions that affect ecosystems, their resources and the resource users and how those decisions are made; who has the power and responsibility to implement those decisions and how those decisions are implemented; and who is held accountable, and how, if decisions are not implemented.

Good governance can support and be supported by an RBA to conservation. ${ }^{59}$ Indeed, the Johannesburg Plan of Implementation adopted at the conclusion of the World Summit on Sustainable Development recognized that "good governance is essential for sustainable development". ${ }^{60}$ Furthermore, according to the UN Office of the High Commissioner for Human Rights, "[A] country cannot achieve sustained progress without recognizing human rights principles (especially universality) as core principles of governance.... The concepts of good governance and human rights are mutually reinforcing." 61

Good governance thus drives conservation and social outcomes, and it can integrate and reconcile diverse interests across natural, cultural, political, and socioeconomic landscapes. Participation in conservation governance can empower communities, including those that are vulnerable and marginalized, and can mobilize their capacities to protect and fulfil their rights while ensuring conservation.

\section{Implementing the Rights-based Approach}

As an important first step towards developing and implementing an RBA, each State should develop and adopt policies, laws, and regulations governing activities that could have negative impacts on conservation. Such measures, including planning or land use laws and EIA or risk assessment procedures, should identify and commit to integrating human rights considerations in the design, prior approval, and implementation of all projects, programmes, and activities, whether undertaken by State agents or non-State actors. In addition to complying with international and local laws,

58 For example: The objective of The World Bank's environmental and social safeguard policies is to prevent and mitigate undue harm to people and their environment in the development process. These policies provide guidelines for Bank and borrower staff in the identification, preparation, and implementation of programmes and projects. For further information on these, see www.worldbank.org/safeguards. The Criteria and Guidelines of the World Commission on Dams (WCD) builds a comprehensive and integrated framework for decision making on water and energy development that incorporates the full range of social, environmental, technical, economic, and financial criteria and standards. This framework is the result of intense study, dialogue and reflection undertaken by WCD, the WCD Secretariat, individual experts, and the WCD Stakeholders' Forum, which brought together members from 68 institutions in 36 countries, including government agencies, affected people's groups, multilateral agencies, NGOs, private-sector firms, and research institutes. For more information, see www.dams.org. Campese, J., Sunderland, T., Greiber, T. and Oviedo, G. (eds.), op. cit. note 2, p. 12.

60 Johannesburg Plan of Implementation, para. 138, at www.un.org/esa/sustdev/documents/WSSD_POI_PD/ English/POlchapter11.htm.

61 United Nations Office of the High Commissioner for Human Rights, FAQ on a human rights-based approach to development cooperation (New York and Geneva: 2006) pp. 10, 16. 
private-sector actors could design their own codes of conduct, as mentioned earlier, or construct a similar publicly available policy commitment to conservation with justice. Components of such codes or policy commitments could include some of the following: ${ }^{62}$

- Recognition that development and other projects and activities have impacts on conservation and human beings, coupled with a commitment to take steps in all cases to minimize environmental harm and ensure respect for human rights.

- Recognition that all stakeholders who are involved in an activity can influence their partners and that all those involved should therefore seek to assist each other to meet their conservation and human rights responsibilities. Supportive actions may include, where appropriate, creating incentives and building capacities for governmental and nongovernmental partners to meet the goal of conservation with justice.

- Recognition that the harmful impact of projects and activities on conservation and human rights often falls disproportionately on the most vulnerable or marginalized individuals and peoples and that efforts need to be made to reach out in particular to these individuals and groups.

- Recognition that there are synergies between conservation and human rights and that these synergies should be identified and promoted through outreach and training, including by bringing together local communities and individuals and organizations with knowledge and experience in conservation and human rights.

- Recognition that ecology, history, culture, governance, economy, law, and other elements contribute to shaping the design and impact of activities on conservation and human rights and that these elements should be investigated and, where appropriate, incorporated into projects and the strategies for implementing them.

- Recognition that increased efforts are necessary to develop and disseminate information about the importance of conservation and respect for human rights in the implementation of all activities and projects.

Once a general RBA framework of laws and policies is in place, it must be implemented with respect to any activity, project, or programme that might have a negative impact on conservation. All programmes designed in accordance with this approach incorporate human rights indicators to monitor and assess the impact of projects and programmes related to conservation. Human rights norms and principles are thus used to identify the initial situation and goals and to assess the impact of the project, programme, or activity. The RBA attaches importance both to the outcome and to the process itself, which should take into account basic principles of nondiscrimination, concern for the most vulnerable and marginalized groups, participation and empowerment, and accountability.

This section describes a step-wise approach that includes some of the significant elements and requirements involved in implementing an RBA. 
Before the impact of any policy, project, or programme can be assessed, it is imperative to understand the circumstances and the context in which it is or will be operating. Pre-project analysis is necessary to get a clear picture of any complex operating landscape.

Overall, the legal, policy, economic, and political framework where the proposed project or activity will take place will strongly influence its conservation and human rights impacts. The State's laws and international environmental and human rights obligations may already be identified and known, but it is essential also to inquire about what rights are being enjoyed or exercised, what obligations are being fulfilled, the environmental conditions, and the circumstances that affect the situation in the potentially affected area. This difficult process may involve several parallel efforts that are interrelated with each other and with the objective of ensuring an RBA to conservation:

- Begin a broad, transparent, and equitable collaboration with interested and affected parties.

- Prepare a comprehensive and transparent plan for development, policy decisions, project definition, monitoring, and evaluation.

- Identify the critical potential conservation and human rights impacts, including for the most vulnerable people(s).

- Begin development of indicators of human rights and conservation consequences to be used throughout the process.

\section{Action 1.1: Identify Actions, Stakehoiders, and Roles}

Communication with all stakeholders, including the potentially affected right-holders and dutybearers, is necessary to implement an RBA to conservation. This, however, demands first identifying what actions might have a negative impact on conservation or rights, who the relevant stakeholders are, and what their roles are.

\section{Required Action Points:}

- Identify the core objectives of the proposed activities and the interests of the proponents (which may create space for later consideration of alternatives that meet these objectives and interests in different ways).

- Identify the potential right-holders, duty-bearers, and other stakeholders.

- Identify project components, partners, and targets, including key benchmarks, focusing on those that appear likely to have negative impacts on conservation or human rights.

- Clarify the powers, limitations, and obligations of the various stakeholders.

- Identify any relevant "lessons learned" from similar prior activities.

\section{Action 1.2: Identify Applicable Legal Rights, Claims, and Duties}

As noted, many internationally recognized human rights are potentially affected by activities that may have a negative impact on conservation, including self-determination and permanent sovereignty over natural resources, life, health, food, housing, information, popular participation, freedom of association, and culture. For any given initiative, only a few rights may be at risk of infringement or 
lack of enjoyment. Thus, part of an RBA involves on-going analysis of which specific rights issues are the most pressing in the given context.

\section{Required Action Points:}

- Determine what rights are recognized (in international, regional, and national law) and enjoyed in the country of operation.

- Identify gaps in the existing legal structure (e.g., core human rights conventions that are not ratified and/or applied in practice; unclear and/or ignored tenure rights).

- Determine what rights are most likely to be affected by the proposed activities.

- Identify rights concerns that have arisen in the past and are relevant to proceeding with the proposed activity.

The identification of relevant rights should include not only local and national law but also regional and international law. Databases of regional and international human rights instruments will indicate which treaties have been accepted by the State ${ }^{63}$ Reports prepared by the government and NGOs and submitted to national, regional, and international bodies as part of the State's obligations under human rights instruments will give additional information about the guaranteed rights, their implementation, and the difficulties encountered in this regard. After analysis, it is important and should be possible to distinguish legal rights, claims, and duties from moral or ethical claims and from claims for legal recognition by a community or.group. As mentioned earlier, legal claims are enforceable while moral or ethical claims impose a moral or ethical duty but not a legal one.

\section{Action 1.3: Identify Potential Impacts of the Proposed Activity or Project}

This process should aim at identifying the current status of the enjoyment of human rights and conservation, as well as determining the key concerns of people within the area likely to be affected by the proposed project or activity. This understanding will help to set goals and enable prediction and measurement of impacts.

\section{Required Action Points:}

- Engage all stakeholders in a participatory pröcess that reflects relevant human rights and principles (e.g., equity, nondiscrimination, transparency, and accountability).

- Develop an understanding of the cultural, ecological, historical, and socioeconomic circumstances of those potentially affected by the project or activity, including de jure and de facto land use and occupation in the area likely to be affected by the activity.

- Identify the concerns of all potentially affected persons, but especially the most vulnerable people(s).

- Attempt to identify structural and other underlying root causes for deficiencies in conservation and rights protection. 
- Assess the baseline context to determine which rights are being respected, protected, and fulfilled for which individuals or groups and the status of natural resources and conservation efforts (assessments should lead to changes in proposed or on-going projects).

- Develop preliminary indicators to measure the impact of the proposed activity on conservation and human rights, given the baseline context (indicators should be developed and used from the beginning of the process and further refined at each step, rather than just at the monitoring or implementation stage). A full set of indicators ${ }^{64}$ should include:

- Structural indicators, which measure whether appropriate legal, regulatory, and institutional structures are in place that are considered necessary or useful for the realization of conservation with justice.

- Process indicators, which provide information on the processes by which the aims of conservation with justice have been respected in the design, implementation, and conclusion of the project or activity.

- Outcome indicators, which provide information on the extent of realization of conservation consistent with human rights.

International agreements and national laws now often require environmental impact assessments that are broad in scope and detailed in their requirements and provisions. Such laws commonly provide that no actor should undertake or authorize a project or activity without prior consideration, at an early stage, of the environmental effects, ${ }^{65}$ and they involve a multistep process of gathering and disseminating information. ${ }^{66}$ However, while the implementation of an EIA will help assess the environmental impact of an activity, the interrelationship between conservation and human rights is not necessarily taken into consideration. As a consequence, EIA does not substitute for an RBA but is only a part of it.

To the degree possible, indicators should be reliable, valid, consistently measurable over time, and possible to disaggregate. Assessing the indicators should lead to changes in policy or action where the results suggest harm is or might be occurring. Ideally, the process should allow for disinterested, independent verification of the assessment.

Espoo Convention (25 February 1991); Article 14(1)(a), Biological Diversity Convention (5 June 1982); Article 4(1)(f), Climate Change Convention (9 May 1992); Article 206, UN Convention of the Law of the Sea (10 December 1982); Article I, Kuwait Regional Convention (24 April 1978); Article 13, West and Central African Marine Environment Convention (23 March 1981); Article 10, South-East Pacific Marine Environment Convention (20 November 1981); Article 14, ASEAN Agreement ( 9 July 1985); Preamble, Amendments to the Protocol for the Protection of the Mediterranean Sea against Pollution from Land-Based Sources, (Syracuse, 7 March 1996); Article III(3), Agreement on the Conservation of Albatrosses and Petrels (2 February 2001). See also Principle 17 of the Rio Declaration (1992) and Principle 11 of the World Charter for Nature (28 October 1982).

In general, the EIA documentation submitted by the originator must contain at a minimum the following: description of the proposed activity and its purpose; statement of the reasonable alternatives, including a no-action alternative; information on the environment likely to be significantly affected and alternative sites; potential conservation or environmental impact of the proposed activity and its alternatives and an estimation of its significance; description of mitigation measures to keep adverse impacts to a minimum; explanation of predictive methods and underlying assumptions as well as the relevant data used; identification of gaps in knowledge and uncertainties encountered in compiling the required information; where appropriate, an outline for monitoring and management programmes and plans for post-project analysis; and non-technical summary, including a visual presentation. 


\section{Action 1.4: Identify Potential Conflict Resolution Mechanisms}

A dispute resolution process should also be designed and implemented, when appropriate, to help resolve conflicts over whether a proposed project or activity should proceed.

\section{Required Characteristics of Conflict Resolution Mechanisms:}

- Bearing in mind that project proponents can partner with and draw on the capacities of others (including human rights NGOs and government bodies), dispute resolution processes should be:

- Made known to all the relevant individuals and communities;

- Well-governed (e.g., equitable, transparent, accountable), legitimate, and independent;

- Complementary to other mechanisms providing access to justice;

- Free for claimants;

- Specific and transparent regarding responsibilities and processes (e.g., consultation and investigation process) to take up and address allegations of harm or rights violations;

- Confidential, where desired, including "whistleblower" protections;

- Fair in providing compensation or restitution, where necessary; and

- Linked to more general policies, programmes, or projects that can be adjusted to avoid repetition of harmful actions.

\section{Provide Information}

Access to information about environmental conditions and proposed activities that might affect conservation as well as human rights is a prerequisite to public participation in decision making and to monitoring governmental and private-sector activities. It also can assist in planning and using the best available techniques for an activity or project. For new or ongoing projects or programmes, the proponent should provide information in order to obtain feedback about any areas of (potential) concern with respect to conservation and human rights impacts that have not already been identified.

\section{Action 2.1: Compile, Publish, and Otherwise Disseminate Information in an Understandable and Easily Accessible Way}

While it is critical for the proponent of an activity or project to gather and assess relevant information about its potential impacts on conservation and human rights, it is equally important that the information is disseminated to the relevant stakeholders in local languages, where appropriate. Information should be disseminated in an adequate manner through appropriate media in order to ensure that it reaches potentially affected persons. In areas where a significant proportion of the population is illiterate, it is particularly important to use non-print media, such as the radio. 


\section{Action 2.2: Disseminate General Information Regarding the Action}

National laws on EIA may regulate the type and amount of information that must be gathered and disseminated. ${ }^{67}$ But even in the absence of such requirements, the proponent of a project or activity should ensure that potentially affected persons are provided with all the information necessary for them to give prior informed consent or otherwise participate in the decision-making process. In particular, the potential conservation impacts and the exact scope of the proposed activity must be described with sufficient detail to permit informed participation.

\section{Action 2.3: Disseminate Specific Information Regarding Legal Rights, Claims, and Duties of Potentially Affected Persons}

Capacity-building efforts should be included throughout the project process and more generally integrated into an RBA to conservation. In particular, part of creating and operationalizing an RBA involves building the capacity of people to understand and claim their rights and the capacity of dutybearers to understand and meet their obligations. For this, project or activity proponents should take the initiative in disseminating information to potentially affected persons about their legal rights and how to exercise them.

Ensure Participation

Public participation is critical to an RBA to conservation. As emphasized in Agenda 21, Chapter 23:

One of the fundamental prerequisites for the achievement of sustainable development is broad public participation in decision-making. Furthermore, in the more specific context of environment and development, the need for new forms of participation has emerged. This includes the need of individuals, groups, and organizations to participate in environmental impact assessment procedures and to know about and participate in decisions, particularly those that potentially affect the communities in which they live and work.

\section{Action 3.1: Undertake Consultations}

First of all, consultations have to be undertaken in good faith, with multistakeholder dialogues exploring the advantages and constraints of different options, with the aim of developing a collective vision of desired outcomes.

Proper consultations call for drawing on knowledge gained in prior steps. Having identified the different stakeholders, including rights-holders and duty-bearers, it should be possible to identify the concerns and interests of those potentially affected and then to develop options in order to negotiate, in mutually satisfactory ways, the activities and policies that can avoid or mitigate risks to conservation and the community. This step in the RBA is one of collectively developing a vision of desired circumstances or optimal results. It should also help to identify compromise positions - what all parties can "live with" as outcomes that will meet the goals of conservation consistent with human rights. At this point, the objectives, goals, and desired impacts and outcomes of actions should be clear and accepted among parties engaged in the process. 
Several problems could arise in the context of consultations. In particular, it may be difficult to determine who speaks for a community and whose voice should be heeded in cases of disagreement within the community. Occasionally the decision-making process of a community may not be compatible with certain international human rights standards (e.g., because it involves discrimination against a part of the community). Project proponents may also face a decision-making process so lengthy that it risks jeopardizing the project. These difficult questions should be addressed transparently and in good faith, where appropriate in cooperation or partnership with others who have relevant expertise or experience with the community. Some guidance is provided by the legal norms themselves. There are, e.g., rights that cannot be suspended or derogated from under any circumstances and that consequently must be given priority in case of a conflict. These include the right to life, freedom from torture and slavery, equality and nondiscrimination, and the judicial guarantees necessary to vindicate rights. Property rights are subject to limitation in the general interest, provided the process is fair and compensation is paid.

Possible options can draw on the resources of a range of actors, including other rights-holders and duty-bearers. Relevant options will vary widely, based on the context. They may include anything from capacity building, advocacy or education, and network building to more technical efforts to clarify tenure regimes, adjust resource access levels, or even adopt more inclusive governance processes (e.g., co-management).

\section{Required Action Points:}

- Develop options aimed at meeting each priority goal. Guiding questions here might include:

- What actions/alternative strategies can the proponent use to avoid or at least mitigate negative impacts on conservation and human rights?

- What actions/alternative strategies can ensure and maximize the benefits that accrue to those potentially affected by the conservation impacts of the project or activity?

- How might the proponent exercise its influence over partners to avoid or at least mitigate negative impacts and support greater benefits for conservation and the community?

- Make efforts to anticipate unintended consequences, including for long-term conservation objectives, other groups, and other rights.

- Develop criteria for choosing among the possible options for action.

- Further refine indicators and monitoring methods for each option to enable assessment of its impacts.

- Agree to, in as inclusive a process as possible, option(s) based on consistency with criteria.

\section{Action 3.2: Seek and Promote Free and Prior Informed Consent}

Like EIA, prior informed consent is a procedural mechanism used in advance of activities in order to avoid potential conflict and reduce the risks of environmental or social harm. The procedure is often used, for example, to control movements of hazardous substances or to mediate access to biological resources, in order to obtain disclosure of potential benefits arising from the access.

The Convention on Biological Diversity, e.g., calls for access to genetic resources on agreed terms and requires that such access be subject to the prior informed consent of the provider country of 
such resources (Article $15(5)$ ). The modalities of the CBD PIC process were elaborated through the Bonn Guidelines adopted by Decision VI/24 of the sixth Conference of the Parties in April 2002. The principles set forth that the system should provide:

1. Legal certainty and clarity;

2. Accessibility, in that access to genetic resources should be facilitated at minimum cost;

3. Transparency: restrictions on access to genetic resources should be transparent, based on legal grounds, and not run counter to the objectives of the convention; and

4. Consent of the relevant competent national authority(ies) in the provider country and the consent of relevant stakeholders, such as indigenous and local communities, obtained as appropriate and according to domestic law.

More generally, in the case of the lands and resources of indigenous and tribal peoples, international norms require that the outcome of good faith consultations must be determined by the peoples themselves. The United Nations Declaration on the Rights of Indigenous Peoples stipulates that States "shall consult and cooperate in good faith with the indigenous peoples concerned through their own representative institutions in order to obtain their free, prior and informed consent before adopting and implementing legislative or administrative measures that may affect them" (Article 19). To comply with international standards, all actors proposing programmes, projects, or activities having an impact on indigenous lands or resources should therefore ensure that free and prior informed consent is obtained.

\section{Required Characteristics of PIC:}

- There is no coercion, intimidation, fraud, or manipulation.

- Information is provided that reveals:

- Nature, size, pace, reversibility, and scope of any proposed project or activity;

- Reasons for it being proposed;

- Duration and range of the affected area; and

- A preliminary assessment of the likely economic, social, cultural, and environmental impact, including potential risks and fair and equitable benefit-sharing in a context that respects the precautionary principle.

- Information is provided in a form that is accessible and understandable, including in a language that people will fully understand.

- Consent is sought sufficiently in advance to allow for traditional indigenous consultation and consensus processes to take place.

- Indigenous peoples specify which representative institutions or individuals are entitled to express consent on behalf of the affected peoples or communities, consistent with the right of nondiscrimination.

- Consultations are undertaken in good faith, establishing a dialogue of mutual respect and full and equitable participation. 


\section{Action 3.3: Provide and Use Conflict Resolution Mechanisms to Secure Rights}

Where consultations and PIC procedures fail to resolve differences between the proponents of a project or activity and those potentially affected, it may be necessary for the parties to use thirdparty mechanisms such as mediation or appeals to administrative or judicial bodies. Rights are intended to be legally enforceable and no project proponent should proceed unless rights have been secured. The conflict resolution mechanisms identified in advance (see action 1.4) should be used first, without prejudice to administrative or judicial procedures.

\section{$4 \quad$ Take Reasoned Decisions}

The first three steps are designed to produce the maximum information and input from all stakeholders about the consequences of a project or activity. Once this has been accomplished, a decision must be taken about the proposed project or activity.

\section{Required Action Points:}

- Check for compatibility with rights and obligations at the international, national, and local levels.

- Check that the decision making has taken place with proper information and participation.

- Include reasons for the decision.

- Disseminate the decision to all relevant stakeholders.

\section{Required Options for Decision-making Result:}

- The project/activity proceeds as envisaged; or

- The project/activity proceeds as modified; or

- A "no action" decision is taken because the detrimental consequences of the project/activity are too severe and cannot be mitigated.

In making the decision, the proponent should keep in mind standards developed by international and national tribunals to review decisions taken for compatibility with human rights. Even assuming all procedural requirements have been followed, an action may still be unwarranted if alternative solutions are available that are less burdensome to guaranteed rights or if the decision fails to strike a fair balance between the benefits of proceeding and the negative impact on particular individuals or groups. The European Court of Human Rights has indicated that it will judge the outcome of a fair process on the merits that an activity authorized as one of benefit to the community in general does not impose a disproportionate burden on any particular individual or group. ${ }^{68}$

\section{Required Characteristics of Reasoned Decision:}

- The project/activity should have a legitimate aim.

- The project/activity should be lawfully undertaken

- The means used should be proportional to the aim, with the test of proportionality being met if there is no unreasonable burden imposed on the affected persons. 
The burden of proof may shift to the proponent to justify (by using detailed and rigorous data) a situation in which certain individuals face severe impacts on behalf of the rest of the community.

\section{Monitor and Evaluate Application of the RBA}

After completion of a project or activity, it is important to undertake an overall evaluation of all the actions and their impacts, to start a policy-practice loop/feedback loop. While prior steps may have been largely predictive, "[m]onitoring events and evaluating their performance will hold a mirror to the assumptions that were made at the outset, to see how these assumptions compare with the actual experience". 69

Monitoring and evaluation will first of all help determine whether the predictions made during the planning phase were accurate or deficient. It also helps to understand whether and how implemented actions are contributing to identified goals (e.g., conservation, mitigation of negative impacts, or rights enhancement). Furthermore, monitoring and evaluation allows consideration of new developments and unintended consequences. The results should help identify what changes need to be made for more effective implementation of an RBA, and ultimately feed back into a cycle of iterative actions and "learning-by-doing" that over time contributes to a more robust and systematic RBA. ${ }^{70} \mathrm{~A}$ full evaluation consistent with the RBA will include communities and persons affected by the project in the evaluation.

Local laws, regulations, or contractual obligations may impose a legal duty to report the result of monitoring and post-project analysis. In other cases someone prepares the report only for his/her own benefit or to maintain consultations with the affected persons or communities. Obtaining and disseminating information about the evaluations undertaken will further implement the RBA.

\section{Required Action Points:}

- Evaluate the application of the RBA through monitoring procedures.

- Use indicators to assess the impacts of steps taken.

- Compare impacts against pre-determined benchmarks.

- Analyse whether actions are contributing to (positive or negative) unintended consequences.

- Evaluate whether and how outcomes contribute to pre-defined objectives.

- Where objectives are not being met, make efforts to understand why (e.g., by going back to a "root causes" analysis).

- Take account of new conditions that may affect conservation or rights.

- Document the process and identify "lessons learned".

- Ensure that monitoring is transparent, consistent, and participatory.

69 International Business Leaders Forum and International Finance Corporation, "Guide to Human Rights Impact Assessment and Management Road-Testing Draft" (June 2007) p. 58. available at http://www.iblf. org/resources/general.jsp?id=123946. The experience gained from the road-testing will be used to further refine the guide. A revised version of the guide will be published by early-2010.

70 Joint UNEP-OHCHR Expert Seminar on Human Rights and the Environment 4-16 January 2002, Geneva: Background Paper No. 1: Human Rights and Environment issues in Multilateral Treaties Adopted between 1991 and 2001, paras 15 and 16, available at http://www.unhchr.ch/environment/bp1.html . 
- Draw on the whole evaluation and lessons learned to develop, collaboratively negotiate, and implement any further change to the policy, project, or activity.

- Transparently report the experiences and draw on lessons learned to seek ways of expanding and strengthening the overall foundation of an RBA.

\section{$6 \quad$ Enforce Rights}

When rights have not been respected or harm occurs, Principle 10 of the Rio Declaration provides that "effective access to judicial and administrative proceedings, including redress and remedy, shall be provided". Agenda 21 calls on governments and legislators to establish judicial and administrative procedures for legal redress in order to remedy actions affecting the environment that may be unlawful or infringe on rights under the law. They should provide such access to justice to individuals, groups, and organizations with a recognized legal interest. As noted earlier, denial of access to justice or failure to afford appropriate redress may allow a case to proceed to a regional or international human rights body, which may determine that the State has failed to comply with its international obligations.

Some instruments, such as the OECD Recommendation on Equal Right of Access in Relation to Transfrontier Pollution (Paris, 11 May 1976), make it explicit that the right to a remedy is not limited to nationals of a State. Both the Convention on Environmental Impact Assessment in a Transboundary Context (Espoo, 25 February 1991) and the Convention on the Transboundary Effects of Industrial Accidents (Helsinki, 17 March 1992) call for equality of access. Article 32 of the UN Convention on the Non-Navigational Uses of International Watercourses (New York, 21 May 1997) formulates the same principle under the title "nondiscrimination".

\section{Possible Options for Remedies:}

\section{- Restoration}

Remediation of environmental harm or restoration of rights that have been infringed is required, where possible, by the preference for restitution as a remedy. It attempts to return those who have been injured to the position they would have been in had the wrong not occurred. Restoration of degraded natural resources is extremely costly and in some instances impossible. It is this reality that has led to the emphasis on prevention of harm.

\section{- Compensation}

Civil actions for damages may be brought by those whose rights have been infringed due to activities or projects that negatively affect their livelihoods or the environmental conditions in which they live. Compensation for any economically assessable loss as well as for moral damages is common and can lead to considerable awards to those who have been harmed.

- Prosecution where Violation Amounts to a Crime

The function of criminal or penal law is to protect the most important values of society by creating and enforcing penalties, including those involving deprivation of liberty. Increasingly, national law is imposing criminal liability on those who have negative impacts on the environment or seriously infringe the rights of others. In most States, not only the company but also its directors and other senior managers may be held responsible for wrongs committed. Normally, a company will be guilty of an offence if the offence-relevant conduct involves instructions or other acts of a "directing mind" of the company. Criminal sanctions can range from fines for petty offences to 
imprisonment for more serious ones. Criminal liability may be primary, accomplice, or conspiracy. In many countries, accomplice liability is imposed on those who give help, support, or assistance to a person committing an offence or who incite, encourage, or counsel such a person. The lesser offence of conspiracy involves a decision by two or more parties to perpetrate an unlawful act. 